\title{
Legitimate and Illegitimate Offspring of Levy v. Louisiana-First Decisions on Equal Protection and Paternity
}

\author{
Harry D. Krause†
}

\begin{abstract}
"Why bastard, wherefore base? When my dimensions are as well compact, $M y$ mind as generous, and my shape as true, As honest madam's issue? Why brand they us With base? with baseness? Bastardy? base, base?"1
\end{abstract}

\section{A New Line OF CASES}

On May 20, 1968, the U.S. Supreme Court decided the "sleeper" of the 1967 term. The Court held twice that a state statute discriminating on the basis of the criterion of illegitimacy violated the equal protection clause of the fourteenth amendment to the United States Constitution. Both cases involved Louisiana's Wrongful Death Act ${ }^{2}$ under which, solely on the criterion of illegitimacy, recovery had been denied the illegitimate child for the death of his mother ${ }^{3}$ and the mother for the death of her illegitimate child. 4

These decisions equalize the legal position of legitimate and illegitimate children vis-à-vis their mother in terms of wrongful death claims against tortfeasors. In their immediate extension, these decisions should eliminate all other legal distinctions between legitimate and illegitimate children in their relation to their mother. ${ }^{5}$ If this were the only meaning of these cases, they would not be important. In most states, the illegitimate child's legal relationship with its mother today is all but equal to that of the legitimate child. The Louisiana statute was exceptional. ${ }^{6}$ This may account for the fact that these decisions went

$\dagger$ Professor of Law, University of Illinois

1 William Shakespeare, as quoted by Justice Douglas in Levy v. Louisiana, 391 U.S. 68, 72 n.6 (1968).

2 LA. Civ. Code ANN. art. 2315 (West Supp. 1967).

3 Levy v. Louisiana, 391 U.S. 68 (1968).

4 Glona v. American Guarantee \& Liab. Ins. Co., 391 U.S. 73 (1968).

6 Michaelson v. Undhjem, 162 N.W.2d 861 (N.D. 1968), discussed in text at note 57 infra.

6 Concerning the origin of the Louisiana statute, see note 31 infra. 
almost unnoticed, rating but a few sentences in a lengthy review of the 1967 term just published in the Harvard Law Review. ${ }^{7}$

But there is more than meets the eye. Since the common law curse of filius nullius still affects the relationship between the illegitimate and his father, the interesting question about the Levy case is whether it will be extended to the father-child relationship. If so, hundreds of state statutes and several federal laws-one effect of which has been to deny one in four Negro children a legal tie with his father-are unconstitutional.

First returns on this question are now in. Perhaps more by accident than by design, the Louisiana Supreme Court-when it heard Levy on remand-assumed without having been asked to decide that the U.S. Supreme Court's decision naturally extended to the father-child relationship. ${ }^{8}$ Two other state supreme courts have squarely contradicted each other. On the appealing and basic issue of the illegitimate child's right of support from his father, the Ohio Supreme Court denied ${ }^{9}$ and the Missouri Supreme Court granted ${ }^{10}$ the child's claim on the basis

7 Note, The Supreme Court, 1967 Term, 82 HARv. I. REv. 63, 293-4 (1968). See also Henkin, Foreword, Id. at $9 \mathrm{I} \mathrm{n.92:} \mathrm{"Henceforth,} \mathrm{for} \mathrm{example,} \mathrm{the} \mathrm{equal} \mathrm{protection} \mathrm{clause}$ will protect a bastard even against distinctions and classifications that have deep roots and can be readily rationalized."

8 This is all the more significant in view of the Louisiana court's outspoken dislike of the U.S. Supreme Court's decision:

The members of this court may totally disagree with the reasoning and the result of the United States Supreme Court majority opinion and may agree with the dissent of Justice Harlan wherein it was said that the majority resolved the issue in this case ... by a process that can only be described as brute force. Nevertheless, it is our obligation to discharge our responsibility under constitutional authority and limitation. ... The United States Supreme Court has held that, as alleged in the petition in this case, when a parent openly and publicly recognizes and accepts an illegitimate to be his or her child and the child is dependent upon the parent, such an illegitimate is a "child" as expressed in Civil Code Article 2315. (Emphasis added.)

Levy v. Louisiana, 216 So. 2d 818,820 (1968).

9 Baston v. Sears, 15 Ohio St. 2d 166, 239 N.E.2d 62 (1968).

10 R- v. R-, 431 S.W.2d 152 (Mo. 1968). See also Armijo v. Wesselius, 440 P.2d 471, 474 (Wash. 1968), decided just prior to Levy v. Louisiana, 391 U.S. 68 (1968), in which the Washington Supreme Court interpreted the wrongful death act to provide for illegitimate as well as legitimate children of deceased parents. The court said:

Significantly, a very persuasive argument can be made that a decision contrary to ours would deny appellant's daughter her Fourteenth Amendment right to equal protection of the laws, since there is no valid social reason, for purposes of welfare legislation, for distinguishing between members of the class 'illegitimate children' and other members of the broader class 'children' to which the members of the more narrow class belong. See H. Krause, Equal Protection for the Illegitimate, 65 Mich. L. Rev. 477 (1967). It is unnecessary for us to reach this constitutional question, however, for it is apparent that construction of a statute to thrust the burden of illegitimacy upon an innocent child would be an unfortunate and ill-advised exercise of our judicial function, and one we choose to avoid.

Cf. Storm v. None, 57 Misc. 2d 342, -, 291 N.Y.S.2d 515, 519 (Family Ct., N.Y. City 1968):

In the light of the decisions of the United States Supreme Court on May 20. 1968, state statutes which discriminate against children on the basis of a classifica- 
of the Levy case. The Ohio holding was weakened by a four to three division, whereas the Missouri decision was unanimous.

The Missouri court held simply that:

[t] he principles applied by the United States Supreme Court would render invalid state action which produces discrimination between legitimate and illegitimate children insofar as the right to compel support by his father is concerned. . . .

The decisions of the United States Supreme Court compel the conclusion that the proper construction of our statutory provisions relating to the obligations and rights of parents ... affords illegitimate children a right equal with that of legitimate children to require support by their fathers. ${ }^{11}$

The Ohio dissent also relied on Levy, but the majority rejected the child's claim and concluded that Levy solely applied to the "intimate, familial relationship which exists between a mother and her child, whether the child is legitimate or illegitimate."12 The court seemed to hold that only the marriage contract can provide the father's consent to be bound to support his child and seemed to view that consent as essential. The court also felt that "[i]f such a dramatic change in social pattern is to be espoused, it should be done by the General Assembly after due deliberation and debate...."13

The Ohio court's objections are not well taken. The point that the father's consent, expressed in his contract of marriage, is the necessary basis for his child's right of support is rendered doubtful by the Ohio paternity statutes which $d o$ provide the illegitimate's mother a support action against the father in many circumstances. The court's deferral to the legislature begs the question, which is whether the equal protection clause requires equality. If it does, it is the courts' duty to ensure equality, with or without implementing legislation and, if necessary, in contravention of opposing enactments. The interesting point of the Ohio case is the court's attempt to distinguish Levy on the facts, on the ground that Levy applies to the mother-child relationship only. This distinction may be proper, but proves nothing. The illegitimate's claim against his father does not rest on an analogy to his claim against his mother. Rather, it rests on comparison with the legitimate child's rights

\footnotetext{
tion as to whether they were born in or out-of-wedlock must be held to violate the Equal Protection Clause of the Constitution. Certainly there is no area in which such statutes should be more carefully scrutinized than where the support, the care, and the education of a child depend on their interpretation. Also cf. Trent v. Loru, 57 Misc. 382, -, 292 N.Y.S.2d 524, 530 (Family Ct., Bronx County, 1968).$$
11 \text { R- v. R-, } 431 \text { S.W.2d I52, } 154 \text { (Mo. 1968). }
$$$$
12 \text { Baston v. Sears, } 15 \text { Ohio St. 2d 166, } 168 \text { n.*, } 239 \text { N.E.2d 62, } 63 \text { n.* (1968). }
$$$$
18 \text { Id. at } 168,239 \text { N.E.2d at } 64 .
$$ 
against his father and, more specifically, on the answer to the question whether "legislation denying to the illegitimate rights [against his father] that are granted to those of legitimate birth is . . . related to a proper public concern with respect to which legitimate and illegitimate children are not situated similarly." 14 This question is the real issue in these cases. It was answered in the Levy case with regard to the child's relationship to his mother to the effect that no proper legislative purposes justify discrimination between legitimate and illegitimate children. Therefore, the applicability of Levy to the facts of the Missouri and Ohio cases should have resulted in an inquiry by the courts: (1) whether there are legislative purposes which support discriminatory legislation in the father-child context that are not present in the mother-child context, and (2) whether such other or additional purposes pass the test of the fourteenth amendment.

Since the Missouri court did not specifically address itself to that question, it may be assumed that the court concluded that there were no legitimate legislative purposes that distinguished the mother-child situation from the father-child situation. The Ohio court, on the other hand, while not being quite specific, seemed to feel that the institution of marriage was somehow more vitally involved in the father-child than in the mother-child context. ${ }^{15}$ Numerous cases on the issue of the applicability of the equal protection clause and the Levy case to the father-child relationship will follow soon. The carelessness of the reasoning in the Levy case invites an attempt to delineate the direction further cases should take. This task is all the more urgent because, in view of current politics embroiling the United States Supreme Court and the prospect of a period of lessened judicial initiative, it may be some time before the Court itself chooses to settle the issue authoritatively.

\section{The Rationale of Levy}

The analytical deficiencies of Levy are illustrated by Justice Douglas' opinion, the operative portion of which follows in full (citations omitted):

In applying the Equal Protection Clause to social and economic legislation, we give great latitude to the legislature in making classifications. Even so, would a corporation, which is a "person," for certain purposes, within the meaning of the Equal Protection Clause be required to forego recovery for

14 Krause, Equal Protection for the Illegitimate, 65 Mich. L. REv. 477, 486 (1967). 15 Baston v. Sears, 15 Ohio St. 2d 166, 167-8, 239 N.E.2d 62, 63.4 (1968). 
wrongs done its interests because its incorporators were all bastards? However that might be, we have been extremely sensitive when it comes to basic civil rights and have not hesitated to strike down an individous classification even though it had history and tradition on its side. The rights asserted here involve the intimate, familial relationship between a child and his own mother. When the child's claim of damage for loss of his mother is in issue, why, in terms of "equal protection," should the tortfeasors go free merely because the child is illegitimate? Why should the illegitimate child be denied rights merely because of his birth out of wedlock? $\mathrm{He}$ certainly is subject to all the responsibilities of a citizen, including the payment of taxes and conscription under the Selective Service Act. How under our constitutional regime can he be denied correlative rights which other citizens enjoy?

Legitimacy or illegitimacy of birth has no relation to the nature of the wrong allegedly inflicted on the mother. These children, though illegitimate, were dependent on her; she cared for them and nurtured them; they were indeed hers in the biological and in the spiritual sense; in her death they suffered wrong in the sense that any dependent would.

We conclude that it invidious to discriminate against them when no action, conduct, or demeanor of theirs is possibly relevant to the harm that was done the mother. ${ }^{16}$

Justice Douglas' inexact analysis, compounded by his irrelevant references to incorporated bastards, ${ }^{17}$ Shakespeare, ${ }^{18}$ and "nonpersons"19 provided an easy mark for Justice Harlan's biting ${ }^{20}$ dissent, whose key argument appears to be the following:

16 Levy v. Louisiana, 391 U.S. 68, 71-2 (1968).

$17 \mathrm{Id}$. at 71. If determined to solve the case by analogy instead of exposition, Justice Douglas might profitably have adopted an analogy made in one of the briefs amici curiae rather than using his own. That analogy related to Plessy v. Ferguson, I63 U.S. 537 (1896), and posed the hypothetical that the State of Louisiana had established a separate public school for children born out of wedlock or barred children born out of wedlock from the benefits of all public education. Brief for Executive Council of the Episcopal Church in the U.S.A. and the American Jewish Congress as Amici Curiae at 13-14, Levy v. Louisiana, 391 U.S. 68 (1968).

18 King Lear, Act I, Scene 2. Quoted at beginning of article, see note I supra.

19 "We start from the premise that illegitimate children are not 'nonpersons". They are humans, live and have their being. They are clearly 'persons' within the meaning of the Equal Protection Clause of the Fourteenth Amendment." Levy v. Louisiana, 391 U.S. 68,70 (1968).

20 "These decisions can only be classed as constitutional curiosities." Id. at 76 (dissenting opinion). "It is, frankly, preposterous to suggest that the State has made illegitimates into 'nonpersons', or that, by analogy with what Louisiana has done here it might deny illegitimates . . . the benefits of doing business in corporate form." Id. at 80 . "He may even, like Shakespeare's Edmund, have spent his life contriving treachery against his family." Id. at 77 n.3. 
Louisiana has chosen, as have most other States in one respect or another, to define these classes of proper plaintiffs in terms of their legal rather than their biological relation to the deceased. ...

The Court today ... rules that the State must base its arbitrary definition of the plaintiff class on biological rather than legal relationships. Exactly how this makes the Louisiana scheme even marginally more "rational" is not clear, for neither a biological relationship nor legal acknowledgement is indicative of the love or economic dependence that may exist between two persons. ${ }^{21}$

This, of course, is "bootstrapping" or, as Justice Douglas himself put it in Glona:

To say that the test of equal protection should be the "legal" rather than the biological relationship is to avoid the issue. For the Equal Protection Clause necessarily limits the authority of a State to draw such 'legal' lines as it chooses. ${ }^{22}$

More cogent is the following portion of the dissenting opinion:

If it be conceded, as I assume it is, that the State has power to provide that people who choose to live together should go through the formalities of marriage and, in default, that people who bear children should acknowledge them, it is logical to enforce these requirements by declaring that the general class of rights that are dependent upon family relationships shall be accorded only when the formalities as well as the biology of those relationships are present. ${ }^{23}$

However persuasive this rationale may be on the Glona case, it does not relate to the problem raised in Levy. Justice Harlan failed to distinguish between the crucially different issues presented by the two cases. The key to Leyy is that the illegitimate child is disadvantaged purely by reason of his birth status over which he has no control, whereas in the Glona situation the mother might have formalized her relationship with her child. ${ }^{24}$ It obviously is not nearly so irrational to deny rights to a person in consequence of his own default than to impose legal disadvantages on someone who is powerless to control his legal status. This does not mean that Glona should have been decided

21 Id. at $79-80$.

$22 I d$. at 75-6.

$23 I d$. at 80.

24 Justice Harlan's argument may be well taken with regard to Louisiana mothers, but fails under the specific facts of Glona, where the mother was a resident of Texas and Texas law would have allowed her action. See Glona v. American Guarantee \& Liab. Ins. Co., 379 F.2d 545, 546 n.2 (5th Cir. 1967). 
differently (Justice Douglas held it to be an irrational exercise of legislative power to connect the mother's sin with the denial to her of recovery in tort for the death of her child), but it does mean that the most important argument that Justice Harlan raised against the Levy and Glona results does not apply to Levy.

An important concern was the question of proof:

$[F]$ or many of the same reasons why a State is empowered to require formalities in the first place, a State may choose to simplify a particular proceeding by reliance on formal papers rather than a contest of proof. That suits for wrongful death, actions to determine the heirs of intestates, and the like, must as a constitutional matter deal with every claim of biological paternity or maternity on its merits is an exceedingly odd proposition. ${ }^{25}$

This argument also fails. (Recovery should be denied in the absence of proof, but granted in the presence of proof. In view of the ease with which maternity may be established in most cases and in view of great scientific progress in ascertaining paternity, ${ }^{26}$ it hardly is rational to consider satisfactory only one type of proof (marriage) and summarily exclude all other proof of parentage. ${ }^{27}$

Justice Douglas' compassionate reference to the dependency of the children on their mother, to the fact that "she cared for them and nurtured them,"28 furnished another target for Justice Harlan's attack:

But an employee who loses a job because of the death of his employer has no cause of action, and a minor child cared for by neighbors or relatives "as if he were their own son" does not therefore have a right to sue for their death. Perhaps most dramatic, a surviving parent, for example, of a Louisiana deceased may sue if and only if there is no surviving spouse or child: it does not matter who loved or depended on whom, or what the economic situation of any survivor may be, or even whether the spouse or child elects to sue. In short, the whole scheme of the Louisiana wrongful death statute, which

25391 U.S. at $80-1$.

26 See Krause, Bringing the Bastard Into the Great Society-A Proposed Uniform Act on Legitimacy, 44 Texas L. REv. 829 (1966).

27 This is not to say, of course, that some standard of proof should not be set. On the contrary, a satisfactory, rational standard of proof of paternity must be set in the very state interest Justice Harlan invokes-the interest "to simplify a particular proceeding by reliance on formal papers rather than a contest of proof." This is especially necessary in paternity matters in which proof tends to disappear more quickly than in many other areas and in which the potential for fraud and blackmail abounds. See text at note 49 infra.

28391 U.S. at 72. 
is similar in this respect to that of most other states, makes everything the Court says about affection and nurture and dependence altogether irrelevant. The only question in any case is whether the plaintiff falls within the class of persons to whom the State has accorded a right of action for the death of another. ${ }^{29}$

But the question under the fourteenth amendment is not whether the illegitimate child was actually dependent on the mother, but whether it stands in a comparable situation with a legitimate child who would recover under the statute whether dependent or not.

Justice Harlan continued:

Louisiana has chosen, as have most other States in one respect or another, to define these classes of proper plaintiffs in terms of their legal rather than their biological relation to the deceased. ${ }^{30}$

But biological relationship is the test that has been used-since time immemorial-in our and other cultures for the fixing of support and other familial obligations, and it is biological relationship that underlies and is traced by legal relationship. To repeat again, our question under the equal protection clause is whether, given the identical biological relationship, there are rational factors that distinguish the legitimate from the illegitimate child for the purposes of a particular law. It will be asserted below that for the proper purposes of some laws such a distinction can and should be made. But Louisiana's Wrongful Death Act is not one of them. Whether, as Justice Harlan implies, the biological relationship test is itself an irrational classification, is a matter that is not reached by Levy $v$. Louisiana nor by any case involving the legitimacy-illegitimacy classification.

Other than a faulty reference to the history of Louisiana's Wrongful Death $A c t,{ }^{31}$ the remainder of the dissent musters no further argument.

$29 \mathrm{Id}$. at $78-9$.

$30 \mathrm{Id}$. at 79.

31 This history was thought to be the same as that of wrongful death statutes in common law states. In fact, however, the discriminatory interpretation of the Louisiana statute is rooted in a tragicomic historical accident which in itself amply demonstrates the irrationality of the Louisiana law involved in Levy. To summarize briefly, the rule stems from Lynch v. Knoop, 118 La. 611, 43 So. 252 (1907), in which a mother of an illegitimate child was denied recovery for the wrongful death of her child. The court stressed the legal distinction between the inheritance rights of legitimate and illegitimate children and noted that, since the statute is in derogation of the common law it should be construed strictly and the term "child" limited to a legitimate child. Ironically, the French law after which the Louisiana Code was patterned had no equivalent to the common law rule under which tort actions died with the victim. Moreover, the basic tort provision 


\section{The Child-Father Relationship Under The Equal Protection Glause}

Whatever the analytical inelegance of Levy, the case prohibits laws discriminating against the person of illegitimate birth in his relationship with his mother because no rational legislative purpose supports such discrimination. Is there another legislative purpose applicable to discrimination in regard of the relationship between father and child? Just what did Louisiana have in mind with its statutory scheme discriminating against the illegitimate?

Seeking to justify the statute, the Louisiana court below had held that "[d]enying illegitimate children the right to recover in such a case is actually based on morals and general welfare because it discourages bringing children into the world out of wedlock."32 In its brief, the State of Louisiana had outlined a related, broader justification for the statutory scheme that discriminates against the illegitimate:

Louisiana's purposes in granting greater rights to legitimates than to illegitimates are not the punishment of illegitimates and not even the discrimination against immorality in sexual behavior. Louisiana's purposes in this area are positive ones: the encouragement of marriage as one of the most im-

of the French Code, which was taken into Louisiana law as the first sentence, LA. Crv. CODE ANN. art. 2315 (West Supp. 1967), had been specifically interpreted to allow a tort right of action to a dependent of a tortiously killed victim prior to the adoption of the identical tort provision in Louisiana. Erhard v. Uttwiller, [1809-11] S. Jur. II 223 (Cour d'appel, Colmar, March 3, 1810); Rolland v. Gosse, [1815-18] S. Jur. I 540 (Cass. civ. Nov. 5, 1818). For no discernible reason, the Louisiana court expressly rejected the French interpretation and instead adopted the common law view, holding that without a specific statute no action could lie for wrongful death. Hubgh v. New Orleans \& C.R.R., 23 La. (6 La. Ann.) 495, 496-7, 54 Am. Dec. 565 (1851) (on rehearing). To rectify this interpretation, Louisiana then added to its law the predecessor statute to its current wrongful death act. See Voss, The Recovery of Damages for Wrongful Death at Common Law, at Civil Law, and in Louisiana, 6 TUL. L. REv. 201, 221 (1932). But French law indirectly came back in the interpretation that was later given the Wrongful Death Act which discriminated against the illegitimate with regard to his relation with his natural mother. Elsewhere, the illegitimate child's relation to his mother usually is legally complete upon birth. French and Louisiana law, however, to this day require that maternity be formally established by the mother's acknowledgment or by a maternity suit. See Savatier, L'évolution de la condition juridique des enfants naturels en droit français 37, 41-2 in DABIN, LE STATUT JURIDIQUE DE L'ENFANT NATUREL (1965). Lasok, Legitimation, Recognition and Affiliation Proceedings, 10 INT. \& CoMp. L.Q. 123, 127-8 (1961); cf. LA. Crv. Code ANN. arts. 203, 242(1) (West 1952). The confusion is total because French law itself does allow the illegitimate to recover for the wrongful death of his mother and even his father. Min. publ. et cons. Scherriff v. Sansen, [1954] D. Jur. 176 (Cour d'appel, Douai, Dec. 10, 1953); Beinheir Ben M'Bark et Gie v. Dame Bousquet, [1954] D. Jur. 777 (Cour d'appel, Rabat, Nov. 12, 1954). See I Mazeaud and Tunc, Traité théorique er pratique de la RESPONSABILITÉ CIVILE DÉliCTUELLE ET CONTRACTUELLE 372 et seq. (5th ed. 1957).

32 Levy v. Louisiana, 192 So. 2d 193, 195 (La. Ct. App. 1967). 
portant institutions known to law, the preservation of the legitimate family as the preferred environment for socializing the child, and the preservation of the security and certainty of property rights linked with family status.

Since marriage as an institution is fundamental to our existence as a free nation, it is the duty of the State of Louisiana to encourage it. One method of encouraging marriage is granting greater rights to legitimate offspring than those born of extra-marital unions. Superior rights of legitimate offspring are inducements or incentives to parties to contract marriage, which is preferred by Louisiana as the setting for producing offspring. ${ }^{33}$

Encouraging marriage is a valid legislative purpose. The fault in Louisiana's argument lies in the constitutional requirement that a fair connection exist between a statute and a valid purpose, between the status of the illegitimate child under the law and his mother's (or father's) conduct. If there is any connection, it lies in the expectation that a potential mother will be so concerned about the treatment that awaits her illegitimate child at the hands of the law that she will adjust her conduct accordingly. The rising illegitimate birth rate tends to show that it is not likely that many potential illegitimate mothers are guided by this. But even if there were an effective relationship, it would not be permissible to punish an innocent non-party for someone else's undesirable conduct. ${ }^{34}$ Justice Douglas held the discrimination

33 Brief for the Attorney General, State of Louisiana as Amicus Curiae at 4-5, 7-8 (Footnote omitted), Levy v. Louisiana, 391 U.S. 68 (1968).

34 See Krause, Equal Protection for the Illegitimate, supra note 14, at 492, n.60. See also Brief for Appellant at 20-2, Levy v. Louisiana, 391 U.S. 68 (1968):

Furthermore, the decision below is violative of the children's due process rights because it denies them rights on the basis of a condition of birth and a status over which they had no control and which they are powerless to correct. This Court has recognized in several contexts that it is impermissible to hold an individual responsible for his status or conduct over which he has no control. [A leading legal philosopher, Professor Lon Fuller, maintains that a rule which an individual has no opportunity to obey is not a law at all but an arbitrary application of governmental force. L. Fuller, THE MORALITY OF LAw, 39, 70-73 (1964).] Robinson v. California, 370 U.S. 660 [1962], involved a California statute making it a misdemeanor for any person to "be addicted to the use of narcotics." The Court ruled that the "status" of narcotics addiction is "an illness which may be contracted innocently or involuntarily," [Id. at 667] and that therefore any punishment for the condition is invalid as "cruel and unusual" under the Eighth and Fourteenth Amendments. Or, as Justice Harlan said in his concurring opinion, to subject an individual to criminal penalty for a condition which he could not control is an "arbitrary imposition" by the State. 370 U.S. at 679 . See also Driver v. Hinnant, 356 F.2d 761 (4th Cir. 1966) ("chronic alcoholism" a disease not punishable as a crime).

A recent article, after discussing the many scholarly reviews of the Robinson opinion, concludes that, "Even the narrowest of these interpretations [supports] the notion that punishing a status involuntarily entered into and which cannot voluntarily be abandoned is unconstitutional." Amsterdam, Federal Constitu- 
"invidious" because "no action, conduct, or demeanor of [the illegitimate children] is possibly relevant to the harm that was done the mother. ${ }^{\prime 35}$ In his concurring opinion in Smith v. King, ${ }^{36}$ Justice Douglas expressed this point even more cogently when he compared the stigma of illegitimacy to the "archaic corruption of the blood, a form of bill of attainder."

There is no reason to think the proper legislative purpose of encouraging marriage any more valid when it is related to legal discrimination in the illegitimate child's relation with his father than when related to the mother. Indeed, the law's failure to impose a substantial economic

tional Restrictions on the Punishment of Crimes of Status, Crimes of General Obnoxiousness, Crimes of Displeasing Police Officers, and the Like, 3 Crim. L. Bull. 205 (1967). This precisely describes the status of the children here, who neither control nor can correct their condition of illegitimacy. [See also the recent decision of the New York Court of Appeals holding that a vagrancy statute violates due process because it penalizes "a condition, such as one resulting from illness, over which an individual had no control." Fenster $v$. Leary, 20 N.Y.2d $309,314,229$ N.E.2d 426, 282 N.Y.S.2d 739 (1967). Two other courts have reached the same result. Baker $v$. Bindner, 274 F. Supp. 658 (W.D. Ky. 1967); Alegata $\nu$. Commonwealth, - Mass. - 231 N.E.2d 201 (1967).]

NAACP $v$. Overstreet, 384 U.S. 118 [1966], is also on point. In this case the Court dismissed as improvidently granted a petition for certiorari which earlier had been granted, limited to the question whether the lower court, by holding the NAACP liable "for acts performed without its knowledge and by persons beyond its control," denied it rights secured by the Fourteenth Amendment. [NAACP v. Overstreet,] 382 U.S. 997 [(1965) granting cert.]. Although a majority of the Court voted to dismiss the petition, thereby expressing no opinion on the merits, four Justices through an opinion of Justice Douglas concluded that it violated the Fourteenth Amendment to hold the NAACP liable for acts over which it had no control. Id., 384 U.S. at 123-26.

Oyama v. California, supra, [332 U.S. 633 (1948)] brings us even closer to the instant case. There the Court struck down California's Alien Land Law that inflicted harm on a child due to the status of his father. In holding that extraordinary procedural burdens could not be imposed on a citizen in proving the ownership of land merely because his father was an alien ineligible for citizenship, the Court reiterated that distinctions based on ancestry are "by their very nature odious to a free people." Id., 332 U.S. at 646 .

The unreasonableness of imposing burdens upon children because of the actions of their parents is exemplified by an explicit constitutional policy. Article III, Section 3, Cl. 2 of the Constitution provides that "The Congress shall have power to declare the Punishment of Treason, but no Attainder of Treason shall work Corruption of Blood, or Forfeiture except during the Life of the Person attainted." While this provision applies in terms only to cases of treason (which had largely occasioned the historic use of corruption of blood in England), it manifests a broader principle of justice-that individuals should not be denied rights because of the behavior of their ancestors which they could not control. [The Louisiana statute also contravenes the biblical injunction that "The son shall not bear the iniquity of the father." Ezekiel 18:20.] In fact, what Louisiana has done here is similar to the medieval form of punishment by which a "felon's blood was attainted or corrupted" with the result that he could not own property himself, "nor could any heir born before or after the felony claim through him." W.S. HOIDSWORTH, 3 HISTORY OF ENGLISH LAW 69 [1923]. Indeed, if corruption of blood is explicitly forbidden by the Constitution with respect to the heinous crime of treason, it certainly should not be permitted in lesser contexts. In this connection, see 18 U.S.C. $\$ 3563$ (1948), which provides generally that "no conviction or judgment shall work corruption of blood or, forfeiture." [Footnotes and additional citations inserted in brackets.]

And, of course, Levy v. Louisiana, 391 U.S. 68 (1968).

35391 U.S. at 72 .

36392 U.S. 309,396 n.5 (1968). 
burden on the illegitimate father may be more likely to encourage illegitimacy than marriage.

A wide variety of other arguments that might be viewed as supporting legal discrimination between legitimate and illegitimate children in their relation with their father have been discussed and refuted elsewhere. ${ }^{37}$ These arguments include a supposed legislative intent to discourage promiscuity, ${ }^{38}$ to protect the family, ${ }^{39}$ to emphasize the actual child-father relationship that exists in a family unit, ${ }^{40}$ and to allow the father a choice in recognizing or not recognizing his child. ${ }^{41}$ No purpose would be served here to repeat this discussion. Suffice it to say that the true basis for the legislatively-imposed discrimination is found in history, not reason. ${ }^{2}$

(There would seem to be only one factor that seriously distinguishes the relation to the father. This is the problem of ascertaining paternity, which will remain the irreducible minimum relevance of birth out of wedlock. ${ }^{43}$ Blackstone (as well as Justice Harlan) had thought this to justify inferior inheritance rights for the illegitimate. ${ }^{44}$ But as discussed above, Justice Douglas put this point where it belongs, into the realm of proof. ${ }^{45}$ If there is no proof, no relation should be imposed. If there is proof, there is no problem.

\section{A. Ascertainment of Paternity}

Equality vis-à-vis the father means nothing if the father remains unknown. The rationale of the equal protection approach (which runs in terms of the rights of the illegitimate child) therefore implies that the interest primarily at stake in the paternity action is that of the child. This contrasts sharply with existing paternity statutes which usually run in favor of the mother and do not concern themselves with "rights" of the child. The primacy of the child's interest will require legislative recognition. At the least, it will be necessary that the child, by his representative, be a party to an action involving his paternity, regardless of other parties (such as the mother) who may assert their

\footnotetext{
37 Krause, Equal Protection for the Illegitimate, supra note 14.

$38 I d$. at 491 .

39 Id. at 492.

40 Id. at 495 .

41 Id.

$42 I d$, at 498 .

43 Id. at $489-91$.

44 I Blackstone, Commentaries on the Laws of England 481 (Kerr, London 1857).

See text at note 25 supra.

45 Glona v. American Guarantee \& Liab. Ins. Co., 391 U.S. 73,76 (1968).
} 
own interests in the same action. ${ }^{40}$ It also must be recognized that it will not be enough merely to provide rights to the child on whose behalf an action is actually brought. Since the child cannot act for himself in the short time after his birth when there is hope of finding the father, a mechanism should be provided to ascertain the illegitimate's paternity whenever possible and desirable in his best interests. Minnesota now has such a law. ${ }^{47}$ Even if no support is sought or if the putative father is unable to pay support and likely to remain so, a proceeding to declare the child's paternity may be a necessary safeguard of an illegitimate child's potential inheritance from his father or paternal relatives. ${ }^{48}$

In this connection, Justice Flarlan's concern with the possibility that the administration of estates will be burdened with paternity litigation is of considerable merit.49 Definite and reasonable standards of proof of paternity will have to be provided legislatively to avoid just that. It seems clear, however, that the legislatures will not be free to set any standard of proof of paternity they deem fit. While there is no doubt that it is "rationally permissible," indeed necessary, that an illegitimate child prove paternity by other means than a legitimate child (who merely shows the marriage certificate of his parents), the fulfillment of the constitutional equality standard cannot be allowed to depend on (and perhaps be thwarted by) unduly burdensome and unreasonable requirements of proof of paternity that a state may wish to set up. The standards that are set must meet the test of reasonableness.

46 The mother should not be allowed to represent the child in this matter, as her short-term interests (avoiding publicity, emotional upset or accepting a settlement) may conflict with the long-term interests of the child in having his paternity established for support, inheritance, and other purpose.

47 Minn. Stat. ANN. § 257.33 (1959), which provides:

It shall be the duty of the commissioner of public welfare when notified of a woman who is delivered of an illegitimate child, or pregnant with child likely to be illegitimate when born, to take care that the interests of the child are safe-guarded, that appropriate steps are taken to establish his paternity, and that there is secured for him the nearest possible approximation to the care, support, and education that he would be entitled to if born of lawful marriage.

48 See text at note 61 infra. A problem with efforts to involve the father is the potential clash with the child's possible interest in being adopted by suitable outsiders. This potential conflict can be alleviated or avoided if the child's best interests are considered decisive. Consider, for example, a provision such as the following [adapted from Krause, Bringing the Bastard Into the Great Society-A Proposed Uniform Act on Legitimacy, 44 TEXAS L. REv. 829, 837 (1966)]:

If a child born out of wedlock has not been legitimated or if his right of support has not been determined in a paternity action or if he has not been adopted in accordance with the law of adoption, within a period of [one] year beginning with the child's birth, a proceeding to determine paternity shall be brought without delay by [insert name of public authority] on behalf of the child. The court shall dismiss the action if, on the basis of the available evidence, the court is satisfied that the proceeding to determine paternity would not serve the child's best interests.

40 Quoted in text at note 25 supra. 
Until such standards are provided by legislation, the equality requirement would seem to imply that a court should accept any proof (if admissible in accordance with the rules of evidence applied in comparable litigation) that tends to establish paternity and, furthermore, that the court should consider paternity established if such proof measures up to the quantum of evidence required in comparable litigation. A conclusive presumption to the effect that available proof of paternity is inadmissible will rarely if ever meet the test of reason. A recent decision of the Wisconsin Supreme Court, ${ }^{50}$ involving an illegitimate child's claim for the wrongful death of his father, will serve to illustrate this. In this case, mother and father had planned to marry and the father was killed by the accident in question prior to the birth of the child. Under these circumstances, the father had not been formally ascertained as required under the intestacy statute to which the wrongful death act referred. Although the court seemed to have no question about the fact of paternity, it nevertheless insisted on compliance with the statutory formality which the father's death had made impossible. Without becoming aware of the constitutional problem, the Wisconsin Supreme Court probably overshot the mark when it refused to consider the proof of paternity that was available in this case. ${ }^{.0 a}$

If it is clear that the test of rationality limits a state's power to exclude certain types of proof of paternity, or to restrict proof of paternity to unreasonably narrow circumstances (such as marriage of the parents,

50 Krantz v. Harris, - Wis. 2d -, 162 N.W.2d 628 (1968).

50a A lower appellate court in New Jersey went off the mark even further when it expressly held the Levy case to be inapplicable to a comparable fact situation, involving comparable laws. Schmoll v. Creecy, Superior Court of New Jersey, App. Div. (Argued Nov. 12, 1968, decided Jan. 10, 1969) (Goldmann, S.J.A.D.) Unconvincingly, the New Jersey court argued the true but irrelevant point that Levy had turned on the interpretation of "children" under the Louisiana act, whereas the New Jersey statute referred to the intestacy statute which excluded paternal inheritance by illegitimate children. As did the Ohio court in Baston v. Sears, note 9 supra, the New Jersey court fell into the conceptual trap of comparing the father-child relationship with the mother-child relationship and found it to differ in terms of certainty of proof of descent, which was thought to justify the discrimination expressed by the intestacy laws. To be correct in this type of analysis, the court should instead have compared the certainty of paternal descent in terms of legitimate and illegitimate status. But even this error was irrelevant inasmuch as uncertainty of paternity in some cases has no rational bearing on other cases where paternity is certain. To repeat, if paternity is uncertain, no relationship should be imposed, but if paternity is as certain as it seems to have been in this casefather and mother had lived for years as man and wife, had held themselves out as such, and had had five children-the court's own reasoning does not apply. (Concerning wrongful death acts that define eligibility in terms of the intestacy laws it should be noted further that the purposes of the two types of laws are different and that therefore, even if it should be held that discrimination under one statute is constitutionally permissible, this does not necessarily carry over to the other.) 
to use àn extreme example), further questions go to other procedural aspécts of the paternity action. Thus, is a state free to require any quantum of proof it pleases? Currently; there is a wide divergence among states in this matter. Some states still follow the historical precedent and view the paternity action as a criminal prosecution, the offense being the crime of bastardy, adultery, or fornication. Other states have shifted the action into the civil sector, but require that an especially high standard of pröof be met, such as "clear and convincing" evidence. Still other states consider the action wholly civil and apply the stàndard of proof normally applicable in civil actions. It mady be considered rather doubtful that rational reasons justify distinguishing the paternity action from other civil actions in terms of the quanitum of proof required for the imposition of what, after all, is a civil liability today. To be sure, this dóes not relate to the question whether the state may prosecute criminally for bastardy, fornication; or adultery to vindicate a supposed public interest. This merely goes to the question of whether, aside from such criminal actions, the state must provide the illegitimate child an opportunity to establish his paternity (a privalte relationship with no bearing on criminal offensès) by means of a civil action.

Other problems that beset, the paternity action ate not related directly to the constitutional argument. It may be hoped, however, that the forthcoming new look at oùr illegitimacy laws under Leyy will go further than the minimum required or implied by the equality standard. Questions such as trial by jury or judge and the weight and admissibility of scientific evidence have gone too long without intelligent answers. It is certain that the current paternity prosecution practice in many metropolitan àreas is abhorrent. Blackmail and perjury flourish, accusation often is tantamount to conviction, decades of support obligation are decided upon in minutes of court time and indigent defendants often go without counsel or a clear understanding of what in involved. ${ }^{\text {} 1}$ But there is an alternative.

Of course, no matter how fair the proceeding might be made to father and child, the involuntary paternity action should be viewed

51 Krause, Equal Protection for the Illegitimate, supra note 14 , at 490-1, nn.57-9. The following quotation from a recent case illustrates that judicial attitudes toward the paternity proceeding have not much changed in 400 years:

A paternity proceeding in its nature has the appearance of a criminal prosecution, but in fact it is a civil proceeding, the main object of which is to compel the putative father to contribute to the support of his illegitimate child to prevent the child from becoming a public charge. (Emphasis added.)

People ex rel. Elkin v. Rimicci, 97 III. App. 2d 470, -, 240 N.E.2d 195, 199 (1968). Concern about public funds was the rationale behind England's paternity act of 1576 (18 Eliz. 1, c. 3). 
only as a last resort after the father fails voluntarily to assume responsibility for his child. The latter will be encouraged by the background threat of an automatic paternity action and should be facilitated by laws making voluntary recognition procedures readily available. ${ }^{52}$

Assuming that paternity has been ascertained in a given case-is there any further justification for denying the illegitimate a legal relationship with his father similar to that enjoyed by a legitimate child? And if, as seems fairly obvious at this point, no permissible legislative purpose supports the wholesale discrimination imposed by our present order on illegitimates as a class, may narrower distinctions fairly be drawn in specific cases?

\section{B. Support $t^{33}$}

The father is responsible for the support of his illegitimate child in all but a few states. Several states provide that a judgment in a paternity action establishes a right of support equal to that of legitimate offspring of the father. More commonly, the illegitimate child has narrower rights to support than his legitimate brother, in terms of the level of support and the duration of the obligation. Are legitimate and illegitimate children situated similarly vis-à-vis their father with regard to questions of support? Perhaps not entirely. It may be argued that the father's daily association with legitimate children in his family unit provides a reasonable distinction. It may also be argued that this very distinction is one of the factors the illegitimate father should equalize. Whatever the answer to this question, no persuasive reason appears for not providing the illegitimate child a right of support that is equal to the right of support of the legitimate child of divorced parents who, today, constitute a large sub-class of legitimate children in a factual setting that readily compares with that of the illegitimate child. Although the mother's station in life may be a relevant criterion, the factors governing the level of support should not take on a different weight solely by reason of the legitimacy status of the child.

\section{G. Inheritance-Intestacy ${ }^{54}$}

At common law, in Blackstone's words, "[t] he incapacity of a bastard consists principally in this, that he cannot be heir to any one, neither can he have heirs, but of his own body; for, being nullius filius, he is therefore of kin to nobody, and has no ancestor from whom any inheri-

52 Cf. "legitimation" provisions in Krause, Bringing the Bastard Into the Great Society

-A Proposed Uniform Act on Legitimacy, supra note 26, at 832-4 (1966).

53 Id. at 848-52.

54 Id. at 854-6. 
table blood can be derived." 55 Today, most states provide that in matters of inheritance the illegitimate occupies the same position with respect to his mother as a illegitimate child. Generally, however, he does not inherit from his father, other than by will or where the father has formally recognized or acknowledged the child. Notable exceptions are Arizona and Oregon where the status of "illegitimacy" has been abolished, and a few other states in which a judgment in a paternity action gives the child the right to inherit from his father. Furthermore, not all intestacy laws allow the illegitimate to inherit from his mother's family and few make provision for inheritance from the father's family. Legitimate children, of course, generally are designated by the intestacy laws as heirs of their father, mother, ancestors and collaterals on both sides. Some states restrict the father's power to disinherit his legitimate child.

Legitimate and illegitimate children are not in all respects situated similarly vis-à-vis their father with regard to their right of inheritance, especially if the intestacy laws are viewed as expressing the typical testator's presumptive intent. As in the case of the child's right of support, the father's daily association with legitimate children in his family unit may provide a distinction that seems reasonable at first glance. ${ }^{56} \mathrm{~A}$ more far-fetched distinction may be the derivation of a preference for the legitimate child from the marital property regime of the common law that still prevails in many states and that gives the wife few rights in her husband's estate although she might be considered to have helped earn it. A preference for the legitimate child thus might be viewed as passing property to the father's legitimate children that is attributable to their mother.

So much for a possibly permissible preference of the legitimate child

55 I Blackstone, Commentaries on the Laws of England 485 (Kerr, London 1857).

56 This facile argument is easily refuted. See Krause, Equal Protection for the Illegitimate, 65 Mrch. L. REv. 477, 495 (1967):

An attractive reason which may be invoked to justify discrimination against the illegitimate is found in the actual, living family relationship a father normally has with his legitimate children, a type of relationship he usually would not have with his illegitimate child. Indeed, legislation which focused on this difference might be difficult to fault, were it not for the fact that the denial of a relationship with his father is precisely the wrong of which the illegitimate is complaining. To argue that because the illegitimate does not have a relationship with his father he should not be entitled to one is bootstrapping. Furthermore, the discriminatory legislation which is attacked here does not define its classes in terms of the actual father-child relationship. Whether living in a family setting or not, the legitimate child enjoys broader rights against his father (whom he might never have seen) than does the illegitimate (who might, in fact, live with his father and mother in a permanent family-like situation). Therefore, even if children might reasonably be classified on the basis of whether they live and share their lives with their fathers, the definition of these two groups by means of the criterion of birth in or out of wedlock is over-inclusive in that it covers children who are legitimate but who do not live with their fathers and underinclusive in that it excludes illegitimates who do live with their fathers. 
in competition with his illegitimate half-sibling. Its constitutionality is not in question. The intestacy laws commonly turn solely on the criterion of illegitimacy and, in the absence of closer legitimate relations, would pass the father's inheritance to a remote, legitimate cousin rather than to his illegitimate child. Nor would a change in the intestacy statute unduly restrict freedom of testation. If, in a particular case, the father would not wish his illegitimate child to take, he would remain free to disinherit him by his will, as he is now free in nearly all states to disinherit his legitimate child.

In the meantime, under traditional intestacy statutes which, without more, apply the criterion of legitimacy, the North Dakota Supreme Court's recent application of Levy $v$. Louisiana to the intestacy laws bodes well for the illegitimate bent on inheriting. ${ }^{57}$ In that case, a nephew and niece claimed the estate of their uncle. Unfortunately for them, however, their grandmother, in addition to producing their deceased uncle legitimately, had also borne a number of illegitimate children who, in turn, had had numerous children. The Court held flatly that the Levy case required that the intestate's illegitimate halfsister and illegitimate half-nephews and nieces were entitled to take without regard to their illegitimate origin.

True, the case involved a common maternal ancestor. The North Dakota court, however, gave little indication ${ }^{58}$ that it saw the Levy case as limited to cases involving legal discrimination in the mother-child relationship:

Applying the reasoning in Levy, as no action, conduct, demeanor of the illegitimate children in the instant case is relevant to their status of illegitimacy, we conclude that the classification for purposes of inheritance contained in $\$ 56-01-05$, which is based on such a status and which results in illegitimate children being disinherited while their legitimate brothers and sisters inherit, is unreasonable.

Accordingly, .... we have no hesitancy in holding that $\S 56-01-05$ is unconstitutional as an invidious discrimination against illegitimate children in violation of $\S 1$ of the fourteenth amendment to the United States Constitution and $\S 20$ of the North Dakota Constitution. This statute, which pun-

57 Michaelson v. Undhjem, 162 N.W.2d 861 (N.D. 1968).

68 Although not significant from the standpoint of the legal issues of this lawsuit, we think it should also be noted that most states have by legislative action departed from the harshness of the common law as it related to illegitimates, and that both California and New York, states from which we have derived much of our code, have changed their laws recently to permit illegitimate children to inherit from and through their mothers. (Emphasis added.)

Id. at 878 . 
ishes innocent children for their parents' transgressions, has no place in our system of government, which has as one of its basic tenets equal protection for all. ${ }^{59}$

Since $\S 56-01-05^{60}$ applied to inheritance from paternal as well as maternal kindred, its unqualified rejection by the court may be read to allow for inheritance by the illegitimate through the father's family as well as from the father, if paternity has been established. The remaining question as to inheritance from and through the father may thus be refined to turn on the type and standard of proof of paternity that a court may ask of a person claiming to be illegitimately related to an intestate through his father. ${ }^{61}$

\section{Inheritance-Wills and Trusts}

In the interpretation of wills and trusts the words "child," "descendant," "heir,". "issue" and similar terms have often been judicially interpreted to refer to legitimate children only. While judicial interpretation of wills and trusts presumably meets the test of state action and thus may be considered subject to constitutional scrutiny, we are dealing here with an area in which the testator or settlor has the broadest freedom. So long as judicial interpretation merely seeks to ascertain his actual intent, rather than substitute its own preference, it would seem to be immune from attack. In many cases, of course, there is no relation between the interpretation and the testator's or settlor's actual intent and arguments analogous to those discussed under the intestacy laws apply.

\section{E. Inheritance and Gift Taxes}

State inheritance tax rates that are applied to bequests to non-relatives (sometimes including illegitimate children) often are higher than

59 Id.

60 N.D. CENT. Code \& 56-0I-05 (1960).

Inheritance by child born out of wedlock.-Every child born out of wedlock is an heir of the person who in writing signed in the presence of a competent witness acknowledges himself to be the father of such child. In all cases such child is an heir of his mother. He inherits the father's or mother's estate, in whole or in part, as the case may be, in the same manner as if he had been born in lawful wedlock. He, however, does not represent his father or mother by inheriting any part of the estate of the kindred of his father or mother, either lineal or collateral, unless before his death his parents shall have intermarried and his father after such marriage shall have acknowledged him as his child or adopted him into his family. In that case such child and all the legitimate children in such family are considered brothers and sisters and on the death of any one of them intestate and without issue the others, subject to the rights in the estate of such deceased child of the father and mother, respectively, as is provided in this code, inherit his estate as his heirs in the same manner as if all the children had been born in wedlock. The issue of all marriages null in law or dissolved by divorce are deemed to have been born in wedlock.

61 See text at note 49 supia. 
inheritance tax rates applied to legitimate children. ${ }^{62}$ The equal protection rationale presumably would require the same inheritance tax rate to be levied on bequests to illegitimate and legitimate children. Similar reasoning applies to state gift taxes. ${ }^{63}$ Federal taxes are not in the picture, because federal estate and gift taxes are not assessed on the

62 Kentucky: Ky. REv. STAT. \& 140.070 (1963) grants special inheritance tax rates to Class A individuals, which includes "child by blood, stepchild, child adopted during infancy." According to 1928 OP. ATT'Y GEN. 208, No. 136, an illegitimate child is not a "child" under the inheritance tax law.

Louisiana: Under earlier inheritance tax law illegitimate beneficiaries belonged to no family and, therefore, could not be classed as ascendants, descendants, or collateral relatives for purposes of inheritance tax exemptions. Succession of Baker, 129 La. 74, 55 So. 714 (1911). The present statute gives special inheritance tax treatment to a "direct descendant, by blood or affinity." LA. REv. STAT. ANN. \& 47:2402(1) (1952). Since the Baker case has not been overruled, it would appear that it still applies. Cf. Succession of Wesley, 224 La. 182, 69 So. 2d 8 (1953).

Nebraska: NEB. REv. STAT. \& 77-2004 (1958) grants special inheritance tax rates to a “. . . child, [or] . . . any lineal descendant born in lawful wedlock . . . ." (Emphasis added.)

New Jersey: N.J. SrAT. ANN. \$ 54:34-2 (Supp. 1968) grants special inheritance tax rates to ". . child or children of a decedent, . . . or the issue of any child . . . The word "child" as used in this provision was construed as excluding illegitimate children. Bank of Montclair v. McCutcheon, 107 N.J. Eq. 564, 152 A. 379 (1930). N.J. STAT. ANN. § 54:342.1 (1960) provides the illegitimate child with the same exemptions as that given to a legitimate child of the decedent, provided the decedent stood in the mutually acknowledged relation of a parent to the child for not less than ten years, such relationship having begun at or before the child's fifteenth birthday. See In re Rogers' Estate, 30 N.J. Super. 479, 105 A.2d 28 (1954), rev'd on other grounds, sub nom Morristown Trust Co. v. McCann, 19 N.J. 568, 118 A.2d 16 (1955).

North Carolina: N.C. REv. STAT. \$ 105-4(a) (1965) grants special inheritance tax rates to Class A individuals, which include "lineal issue." However, according to 1944-46 Op. ATT'Y GEN. 112 (April 3, 1945) illegitimate children are excluded from the special rates if they are not legally adopted by the father. 2 CCH INH. EST. \& GIFT TAX REP. (N.C.) 11310.74 (1966).

Pennsylvania: PA. STAT. ANN. tit. 72, \& 2485-403 (1964) grants special inheritance tax rates to Class A individuals, which include "lineal descendants." PA. STAT. ANN. tit. 72, $\S$ 2485-102(13) defines "lineal descendants" as including "illegitimate descendants of the mother and their descendants, and children and their descendants of the natural parent who are adopted by his spouse. It does not include . . . illegitimate children of the father and their descendants . ..."The same exclusion of illegitimate children of the father is also found in the definition of "children." PA. STat. ANN. tit. 72, § 2485-102(3).

Texas: TEX. TAX-GEN. art. 14.02 (1960) grants special inheritance tax rates to Class A individuals, which include "... any direct lineal descendant of husband or wife, or any direct lineal descendant or ascendant of the decedent . . . ." According to 1958 DiGEST of OP. ATT'Y GEN. 28, No. 481, the father must "legitimate" the child as required by statute in order to make his illegitimate child his heir. If this is not done, the illegitimate child is not considered the "lineal descendant" of the father for the purpose of the inheritance tax classification provisions. Cf. Eckford v. Knox, 67 Tex. 200, 203, 2 S.W. 372, 373 (1886).

63 The gift tax laws of at least two states, LA. REv. STAT. ANN. §§ 47:1205(1), 1206(1) (Supp. 1967) and N.C. GEN. STAT. \& 105-188(f)(1) (1965), would seem to be subject to discriminatory interpretation similar to that given the inheritance laws of these states, since special treatment is provided for the same groups preferred under the inheritance laws. See note 62 ; supra. 
basis of the relationship of the deceased to the recipient (except in the case of the marital exclusion).

\section{F. Visitation, Custody, Adoption 64}

An unwilling father's affection cannot be legislated. Present law, however, gives even the willing father few or no rights with respect to his illegitimate child. Such rights may be derived from the interest of the child in having his father participate in decisions affecting his welfare, or from a variation of the equal protection argument to the effect that, because he and the mother are situated similarly with respect to the child's custody and related issues, it would deny the father equal protection if he were not given such rights. No rational legislative reason justifies not hearing the interested father who fairly and regularly contributes to the support of his child on issues such as the child's general welfare, including his custody and education. The willing father's participation also should extend to adoption matters, and the appropriateness of an adoption should be considered in the light of the interests of all three parties involved: the father, the mother and the child. By analogy to statutes allowing the involuntary termination of parental rights, this does not mean that the father should have a power of "veto" over the adoption of his child.

A countervailing consideration is that the state's interest in maintaining the integrity of the family becomes forceful in this area. If the father has a legitimate family, his wife could hardly be forced to accept an extra-marital child into her home. Thus, on superficial inspection, laws distinguishing between illegitimates and legitimates for purposes of defining rights of visitation and custody do not seem as vulnerable as other instances of legislated discrimination. However, on closer inspection, present law does fail the equal protection test because it decides these questions on the basis of the criterion of legitimacy alone. This approach takes no account of the actual family situation. Often a family may not be in the picture, or the family involved may not be entitled to consideration. Thus, if the father decides to establish a new family, the illegitimate should not be deprived of any rights against his father which a legitimate child of a former marriage could not be forced to relinquish.

\section{G. Paternal Name $e^{65}$}

The illegitimate's claim to his father's name cannot be advanced as a general proposition. Here there are some rational distinctions be-

\footnotetext{
64 See Krause, Bringing the Bastard into the Great Society-A Proposed Uniform Act on Legitimacy, supra note 26.

65 Id. at 858 .
} 
tween the child born into a family and the illegitimate. At least one function of the "family" name of the father is to identify those persons who live with him in an economic and social unit. This purpose would not be served if the father's name were given to an illegitimate who does not live with him. In addition, the mother has a proper interest in naming the child after herself, especially if she lives in a social and economic unit with her illegitimate child. On the other hand, the use of the father's name by the child indicates his ancestry and, given the right father, the name can be of value. A proper answer probably should be based on a case by case evaluation of these conflicting considerations in the light of the best interests of the child, the mother, and the father.

\section{H. State 66 and Federal "Welfare Laws"67}

State and federal "welfare" laws often tie a child's eligibility for benefits to a father who is primarily "covered" by the legislation in question. Examples on the state level are workmen's compensation laws and wrongful death acts. A growing number of such enactments provide or have been interpreted to mean that the illegitimate child is entitled to the rights of a legitimate child. However, in many states illegitimate children of a covered father remain ineligible for benefits under these laws.

Under federal statutes providing benefits for children, eligibility for benefits often is derived through the child's father, who has "earned" the benefit by membership in a given class or otherwise. These federal statutes include the Longshoremen's and Harbor Worker's Compensation Act, the Foreign Service Act, various items of veterans' legislation, the Social Security Act, the Federal Death on the High Seas Act, the Federal Group Life Insurance Act, the Copyright Act, and the Jones Act. These statutes are not consistent in whether or not they provide benefits for illegitimate children. More recently, federal welfare laws (especially the Social Security Act) have moved toward eliminating discrimination against the illegitimate, but considerable deference to state policy in the field of family relations remains and this usually spells a disadvantage for the illegitimate.

To paraphrase an enlightened federal judge: The purpose and ob-

$6 B$ Id. at 856.

67 See Krause, Equal Protection for the Illegitimate, supra note 14, at 480-2. With respect to Federal legislation, the equal protection rationale must be channeled through the fifth amendment, which does not express a requirement of equal protection. This would not seem to be a serious hurdle. See Bolling v. Sharpe, 347 U.S. 497 (1954); The Constitution of the United States of America, S. Doc. No. 39, 88th Cong., Ist Sess. 973-5 (1964). 
ject of welfare statutes is to continue the support of dependents after a casualty. To hold that illegitimate children do not come within the terms of these acts defeats the purpose of the acts. ${ }^{68}$ No more need be said.

68 Judge Manton in Middletown v. Luckenbach S.S. Co., 70 F.2d 326, 330 (2d Gir.), cert. denied, 293 U.S. 577 (1934). Especially under welfare statutes, discrimination on the basis of illegitimacy often brushes perilously close to racial discrimination. This may be illustrated by the actual operation of the Louisiana Wrongful Death Act involved in the Levy case. In his brief for the NAACP Legal Defense and Educational Fund, Inc. and National Office for the Rights of the Indigent, as Amici Curiae, Levy v. Louisiana, 391 U.S. 68 (1968), this author noted that, although the Louisiana Wrongful Death Act employed no racial criterion on its face, it operated far more severely upon Negroes as a class than it does upon whites. This covert discrimination came about in two ways. First, disproportionately more Negro children than white children are born out of wedlock. In Louisiana in 1965, the U.S. Department of Health, Education and Welfare reported, 8,276 illegitimate children were born to Negroes and 1,158 were born to whites. U.S. NEWS AND WORLD REPORT, Oct. 2, 1967, at 85. The national picture is similar. In 1963, the Vital Statistics Division of the Public Health Service, U.S. Department of Health, Education and Welfare, estimated that the white illegitimacy rate was 30.7 per 1,000 live births; the non-white rate was 235.9. (While the non-white classification includes Orientals, Indians and Negroes, Negroes so predominate numerically (more than 90\%) that the non-white classification reflects the Negro figure with reasonable accuracy. U.S. Bureau of the Census, Statistical Abstract of the United Statrs 28 (1967).) See United States Department of Labor, Office of Policy Planning and Research, The Negro family, The Case for National Action (hereafter referred to as The Moynihan REPORT) 8-9, 59. By 1965, the white rate was 40 and the Negro rate was 263 per thousand live births. U.S. NEWS AND WORLD REPORT, Oct. 2, 1967, at 85. These figures drastically understate the problem, for among the impoverished urban Negroes the illegitimacy rate has been rising much faster than it has risen nationally. In the District of Columbia, the illegitimacy rate for non-whites grew from 21.8 percent in 1950, to 29.5 percent in 1964. THE Moynihan Report at 9. In impoverished areas of the District, the 1963 rate was 38 percent. $I d$. at 70. In Harlem, the non-white illegitimacy rate in 1963 was more than 43 percent. $I d$. at 19 . In some areas of Chicago, the illegitimacy rate stands at 38 percent. Champaign-Urbana [Illinois] News Gazette, Feb. 14, 1966, p. 13. In Central Harlem, illegitimacy stood at 54.2 percent in 1967 . N.Y. Times, July 1, 1968, at 21.

The second and even more important reason that made the statute disproportionately more burdensome for Negroes than for whites is that a high percentage $(70 \%)$ of white illegitimate children are adopted and thereby achieve status under the Wrongful Death Act, at least with regard to their adoptive parents, whereas very few $(3-5 \%)$ Negro illegitimates find adoptive parents. U.S. DEPARTMENT of HEALTH, EduCATION AND WELFARE, Illegttimacy and ITs Impact on the Ayd to Dependent Children Program 35-6 (1960).

Griffin v. County School Board, 377 U.S. 218 (1964), involved a comparable point because, on its face, the closing of the public schools of Prince Edward County to white and Negro children was not discriminatory. However, the Supreme Court unanimously held the school closing "to deny colored students equal protection of the laws" because "[c]losing Prince Edward's schools bears more heavily on Negro children in Prince Edward County since white children there have accredited private schools which they can attend while colored children until very recently have had no available private schools, and even the school they now attend is a temporary expedient." If the uneven numerical incidence of illegitimacy among Negroes and whites in itself provides an analogy, the fact that adoption facilities are open and widely utilized by white illegitimates improves the analogy. The analogy was perfected by a Louisiana statute which 


\section{The Meaning of "Equality"}

The question now arises whether equality should be sought through legal neutrality or whether the law must act affirmatively to help the illegitimate approximate the situation of the legitimate child. As mentioned above, ${ }^{69}$ affirmative action to ascertain paternity would seem indicated whenever this is possible and in the child's best interests. A more difficult question is whether the illegitimate's right of support is to be extended beyond the father's death by providing a liquidated support claim against the father's estate. This would make the illegitimate somewhat more than equal since the father may disinherit his legitimate child without making provision for support. ${ }^{70}$ With respect to most other problem areas, however, even "if legal neutrality is inadequate to compensate for inequality in fact, to have the law take affirmative steps toward factual equality opens ... a Pandora's box of difficult problems of value judgment, prejudice and preference." 71 While somewhat similar problems are now being discussed at the fringes of the

forbids interracial adoption and thereby closes to Negroes, solely on the ground of race, one method of escape from the discrimination under the Wrongful Death Act. LA. REv. STAT. \& 9:422 (1965). (Loving v. Virginia, 388 U.S. I (1967), of course, presumably voids this statute.)

Applying the national percentage on white adoptions $(70 \%)$ and non-white adoptions (4\%) to the 1965 Louisiana illegitimacy figures (1,158 white, 8,276 Negro); it may be estimated that only 347 white children remained unadopted, whereas 7,945 Negro children remained unadopted. This means that 95.8 percent of all persons potentially affected by the operation of the Louisiana Wrongful Death Act were Negroes. For all practical purposes this means that the criterion of illegitimacy as used under the Louisiana Wrongful Death Act was synonymous with a racial classification.

It was not contended, of course, that the construction of the Louisiana statute against illegitimates, at least in its inception, had a racially discriminatory intent. Nor was it contended that a statute which happens to fall most heavily upon one particular group is for that reason alone unconstitutional. However, it was suggested to the Court that Louisiana is a Southern state with a long history of racial discrimination and that the operation of the Wrongful Death Act, if accidentally, fits perfectly into a pattern of legislation which often is only a thinly disguised cover for racial discrimination. For example, in 1960 Louisiana amended its constitution to deny the right to vote in federal and state elections for a period of five years after the birth of an illegitimate child, to both parents of an illegitimate child. LA. Consr. art. 8, $\S \S 1(c)(5)$, (6). See Brief for NAACP Legal Defense and Educational Fund, Inc. and National Office for the Rights of the Indigent as Amici Curiae at 18-20, Levy v. Louisiana, 391 U.S. 68 (1968). The Supreme Court, perhaps wisely, stayed clear of this aspect of the controversy.

60 Text at note 46 supra.

70 Arguably, however, the illegitimate is more in need of such protection than is the legitimate child. Note that such regulation may provide a disinherited legitimate child with an equal protection argument!

71 Krause, Bastards Abroad-Foreign Approaches to Illegitimacy, 15 AM. J. CoMP. L. 726, 751 (1966-67). This article provides a detailed discussion and critique of acțive efforts toward reform in the law of illegitimacy that are under way in Europe. 
racial equality requirement, ${ }^{72}$ the illegitimate's claim probably should be limited to the degree of equality that neutral laws can furnish.

To be sure, much of the national problem of illegitimacy-one in fifteen children is now born illegitimate ${ }^{73}$-lies in the public sector and requires public help in social and economic terms. But there it lies as an integral aspect of the poverty problem and the criterion for public help is poverty, not illegitimacy. If, by reducing social and economic poverty, public relief also reduces illegitimacy and some of its burdens, this does not overlap with the ground covered here. Here the focus is on the private resources that the law should make available to the illegitimate to provide him an even start in life. These resources are his parents, especially his father. Although public relief must alleviate some of the worst aspects of illegitimacy, in a society that thinks in terms of individual-not collective-responsibility, the relief that is the subject of this paper must ultimately take over the task. To repeat, our illegitimacy laws deny one in four Negro children a legal relationship with their father. Under some illegitimacy laws, ten or twenty times more blacks than whites are affected. ${ }^{74}$

\section{Conclusion}

Whatever the conclusion as to any specific instance of discrimination, no rational reason supports the wholesale discrimination imposed by our present legal order. It seems clear that a great advancement in the legal position of the illegitimate will be realized under the Levy case without harm to existing institutions. The family will not cease to exist. This is a tired concern. For example, in the eighth century, St. Boniface described the English "both Christians and pagans, as refusing to have legitimate wives, and continuing to live in lechery and adultery after the manner of neighing horses and braying asses," and wrote to King Ethelbald: "Your contempt for lawful matrimony, were it for chastity's sake, would be laudable; but since you wallow in luxury, and even in adultery with nuns, it is disgraceful and damnable .... Give heed to this: if the nation of the Angels, ... despising lawful matrimony, gives free indulgence to adultery, a race ignoble and scorning God must necessarily issue from such unions, and will destroy the country by their abandoned manners." 75

We still have adultery and we still have families. Indeed, if we did

72 See Kaplan, Equal Justice in an Unequal World: Equality For the Negro-The Problem of Special Treatment, 61 Nw. U.L. REV. 363 (1966).

73 See statistics cited note 68 supra.

74 Supra note 68.

75 Durant, The Age of Faith 487 (1950). 
not still have families, there could be no adultery. Similarly, if there were no families, there would be no legitimacy, and consequently no illegitimacy. ${ }^{76}$ If equal rights are sought for the child without a family, it is only on the assumption that the family will remain.

The equal protection clause has set the standard that must be met. We may rely on the courts to chart a haphazard route through the difficult questions touched on above and see the answers vary from case to case and court to court. On the other hand, we may answer the complicated question of whether legitimates and illegitimates are situated similarly for the fair purposes of a particular law through detailed, preferably uniform, legislation that centers on the interests of the child and embodies the equality principle of the fourteenth amendment. The latter course seems clearly the better. ${ }^{77}$

70 Have the Ethiopians achieved the perfect solution? "Le mariage est prohibe entre parents." Art. 582, Parenté, Code: Livre II, titre IV, Ch. III in R. DAvid, LE DroIT DE IA Famille dANS le CoDe Civil ExhIOpIeN (1967).

77 See draft statute in Krause, Bringing the Bastard Into the Great Society-A Proposed Uniform Act on Legitimacy, supra note 26, at $832-41$, which may furnish a basis for discussion. It is a hopeful portent that the National Conference of Commissioners on Uniform State Laws has recently established a committee on a "Uniform Legitimacy Act" to study the matter. 